УAK 657.1

I. Maksymenko,

$\mathrm{PhD}$ in Economics, Associate Professor, Associate Professor of the Department of Accounting and Taxation, National University "Zaporizhzhye Polytechnic"

ORCID ID: 0000-0002-2362-6183

S. Nech,

Master's student 6th year of the Department of Accounting and Taxation, National University "Zaporizhzhye Polytechnic"

ORCID ID: 0000-0002-6523-513X

DOI: $10.32702 / 2306-6792.2021 .21 .87$

\title{
PECULIARITIES OF ACCOUNTING OF PAYMENTS TO EMPLOYEES IN THE MANAGEMENT SYSTEM OF THE ENTERPRISE ACTIVITY
}

\author{
I. Я. Максименко, \\ к. е. н., доцент, доцент кафедри обліку та оподаткування, Національний університет "Запорізька політехніка" \\ С. С. Неч, \\ магістрант кафедри обліку та оподаткування, Національний університет "Запорізька політехніка"
}

\section{ОСОБАИВОСТІ ОБАІКУ ВИПААТ ПРАЦІВНИКАМ У СИСТЕМІ УПРАВАІННЯ АІЯЛЬНОСТІ ПІАПРИЕМСТВА}

The article proves that payroll accounting is the most time-consuming and complex in the accounting system of the enterprise, which is why a reasonable and well-structured organization of payroll accounting is important to ensure the accuracy of the data of the object of accounting.

It is determined that the salary is a remuneration, calculated, as a rule, in monetary terms, which under the employment contract the employer pays to the employee for the work performed by him.

It is established that current payments to the employee - payments to the employee which are subject to payment in full during twelve months after the end of the month in which the employee performed the relevant work. It is determined that the payment of wages is one of the key operations in the relationship between employees and the employer.

It is said that the main factor influencing the efficient operation of enterprises is labor costs. Like any other classification, the overall goal of cost classification is to create an orderly organizational cost structure. Without such a structure, it is impossible to effectively keep records and link costs to facilities. Although the classification of costs is done through financial accounting, it does not always meet the information needs of management.

The rules of its payment are simple, but there are many questions about the timing, frequency and other nuances of payment of wages. Analytical accounts for account 66 "Calculations of employee benefits" are proposed, which can be used to make more accurate and efficient salary calculations for a large number of employees.

It is stated that the proposed proposals and measures for improvement to overcome the shortcomings of wage accounting and ensure the convenience of enterprises.

It is established that one of the important areas that have been identified to improve corporate accounting for a more accurate calculation of wages is the introduction of additional sub-accounts in existing analytical accounts and the provision of additional payments to employees.

It is proved that the implementation of the established directions of improvement of calculation of payments to employees will allow to eliminate legislative differences, to increase efficiency of the account, to reduce expenses of time for the account of payments to employees.

У статті доведено, що облік заробітної плати є найбільш трудомістким і складним у системі обліку підприємства, саме тому для забезпечення точності Ааних об'єкта обліку важлива розумна і добре структурована організація обліку заробітної плати.

Визначено, що заробітна плата - це винагорода, обчислена, як правило, у грошовому виразі, яку за трудовим Аоговором роботодавець виплачує працівникові за виконану ним роботу.

Встановлено, що поточні виплати працівнику - виплати працівнику, які піАлягають сплаті в повному обсязі протягом дванадцяти місяців по закінченні місяця, у якому працівник виконував відповідну роботу.

Визначено, що виплата зарплати - це одна 3 ключових операцій у відносинах між працівниками та роботодавцем. Правила їі виплати нескладні, але виникає безліч запитань щодо строків, періодичності та інших нюансів виплати заробітної плати.

Констатовано, що основним фактором, що впливає на ефективну роботу підприємств, є витрати на оплату праці. Як і будь-яка інша класифікація, загальна мета класифікації витрат полягає у створенні впорядкованої структури організаційних витрат. Без такої структури неможливо ефективно вести облік і прив'язувати витрати до об'єктів. 
Хоча класифікація витрат здійснюється за допомогою фінансового обліку, вона не завжди відповідає інформаційним потребам керівництва.

Запропоновано аналітичні рахунки до рахунка 66 "Розрахунки за виплатами працівникам", за допомогою яких можна зробити більш точні та ефективні розрахунки заробітної плати Аля великої кількості працівників підприємства.

Констатовано, що запропоновані пропозиції та заходи щодо вдосконалення Аля подолання недоліків обліку заробітної плати та забезпечення зручності діяльності підприємств.

Встановлено, що одним із важливих напрямів, які були визначені для покращення корпоративного обліку Аля більш точного розрахунку заробітної плати, є введення додаткових субрахунків в існуючі аналітичні рахунки та наАання додаткових виплат працівникам.

Аоведено, що реалізація встановлених напрямів удосконалення розрахунку виплат працівникам дозволить усунути законодавчі відмінності, підвищити ефективність обліку, зменшити витрати часу на облік виплат працівникам.

Key words: wages, current payments, payments for employees, payroll.

Ключові слова: заробітна плата, поточні виплати, розрахунки за виплатами прачівникам, фонд оплати прачі.

\section{FORMULATION OF THE QUESTION}

Private enterprise wage policy is an integral part of enterprise management, and it greatly affects the efficiency of its work, because wages are one of the most important incentives for the rational use of labor, on the one hand, and one of the main components of the enterprise. At any enterprise this section of the account is conducted as a rule, it is difficult and labor-consuming. That is why the problematic issues of payroll accounting require in-depth research, as their solution, in turn, will positively affect the formation of reliable information on the calculation of wages of employees, both tax and statistical accounting in general.

\section{ANALYSIS OF RECENT RESEARCH AND PUBLICATIONS}

Many publications have been written on the topic of accounting for payments to employees, and many authors and scholars have repeatedly returned to this issue, reviewing and researching it. The methodology of accounting for payments to employees is part of the scientific interests of many domestic and foreign researchers. The issue of accounting and taxation of payments to employees has interested scientists of all times, a special theoretical and methodological contribution made by the following scientists: F.F. Butynets, V.M. Gayets, S.F. Golova, G.I.Dakhno, L.O. Kadurina, I.M. Pavlyuk, H. Anderson, G. Alexander, S. Barnes, J. Bailey, R.G. Eccles, B. Needles, and others.

Purpose of article is the substantiation and disclosure of problems of accounting for payments to employees, in order to find ways to solve them.

\section{PRESENTATION OF THE MAIN MATERIAL}

As is known, payroll accounting is the most time consuming and complex in the enterprise accounting system, and that is why a reasonable and well-structured organization of payroll accounting is important to ensure the accuracy of the data of the object of accounting.
Wages are remuneration, calculated, as a rule, in monetary terms, which under the employment contract the employer pays to the employee for the work performed by them.

The totality of all labor costs forms the wage fund. It consists of:

- basic salary fund;

- additional salary fund;

- other incentive and compensation payments.

Along with the payments included in the payroll, there are other payments that do not belong to the payroll. Of these, the most common are:

- sick leaves;

- maternity benefits;

- severance pay;

- one-time financial assistance.

According to PSOA 26 current payments to the employee are payments to the employee, which are subject to payment in full within twelve months after the end of the month in which the employee performed the relevant work.

Payroll is one of the key transactions in the relationship between employees and the employer. The rules of its payment are simple, but there are many questions about the timing, frequency and other nuances of payment of wages.

In the system of analytical accounting the crucial role is played by the collection of information about the worked and unworked time, the fulfillment of the norm by the employee, the composition of employees, the structure of the payroll. Information on labor costs has a significant impact on the formation of the actual cost of production.

In the analysis of the accounting system the most important role is played by information about working and non-working hours, compliance with the rules, the composition of employees, the structure of the payroll.

Estimated information with the company's staff on wages (all types of wages, bonuses, benefits, etc.) and the amount of wages paid by employees, which 


\begin{tabular}{|l|l|}
\hline & Current payments to employees \\
\hline salaries by tariffs & \\
\hline other payroll charges & $\begin{array}{l}\text { bonments for overtime } \\
\text { completion the period, in which employees perform the relevant work }\end{array}$
\end{tabular}

Fig. 1. Current payments to employees according to PSOA 26

Terms of salary payment for the first and second half of the month

Employers are required to pay employees at least twice a month. When determining the terms of payment of wages, it is necessary to simultaneously fulfill

2 requirements. Therefore, salary for the first half of the month (or as it is called advance payment) and for the second half of the month are paid:

1) after a period of time not exceeding 16 calendar days;

2) no later than 7 days after the end of the period for which the salary is paid

\section{L}

The first half of the month is considered to be 15 calendar days from the 1 st to the 15th. Accordingly, the second half of the month - the next calendar days of the month, starting from the 16th and until the last calendar day of the month

\section{Fig. 2. Terms of salary payment for the first and second} half of the month

was not received on time (settlements with depositors), are summarized in account 66 "Payments to employees".

Account 66 "Payments to employees" is designed to summarize information on payments to employees, which belong to both the accounting and non-accounting composition of the enterprise - for wages (for all types of wages, bonuses, benefits, etc.), for amounts not received in due time from the company's cash register on payments to employees, on other current payments.

The credit of this account reflects the accrual of the employees due to them, and the debit - repayment of the employer's arrears on such payments, withholding of personal income tax and military duty, payments on executive documents, as well as other deductions.

Given the above, we consider it appropriate to expand the analytical accounts to account 66 "Calculations for employee benefits" (table 1).

Suggestions for improving analytical accounts can make more accurate and efficient payroll calculations for a large number of employees.

\section{CONCLUSION}

The basis of effective activity of business entities is a reliable accounting system. The main factor influencing the efficient operation of enterprises is the cost of labor. Like any other

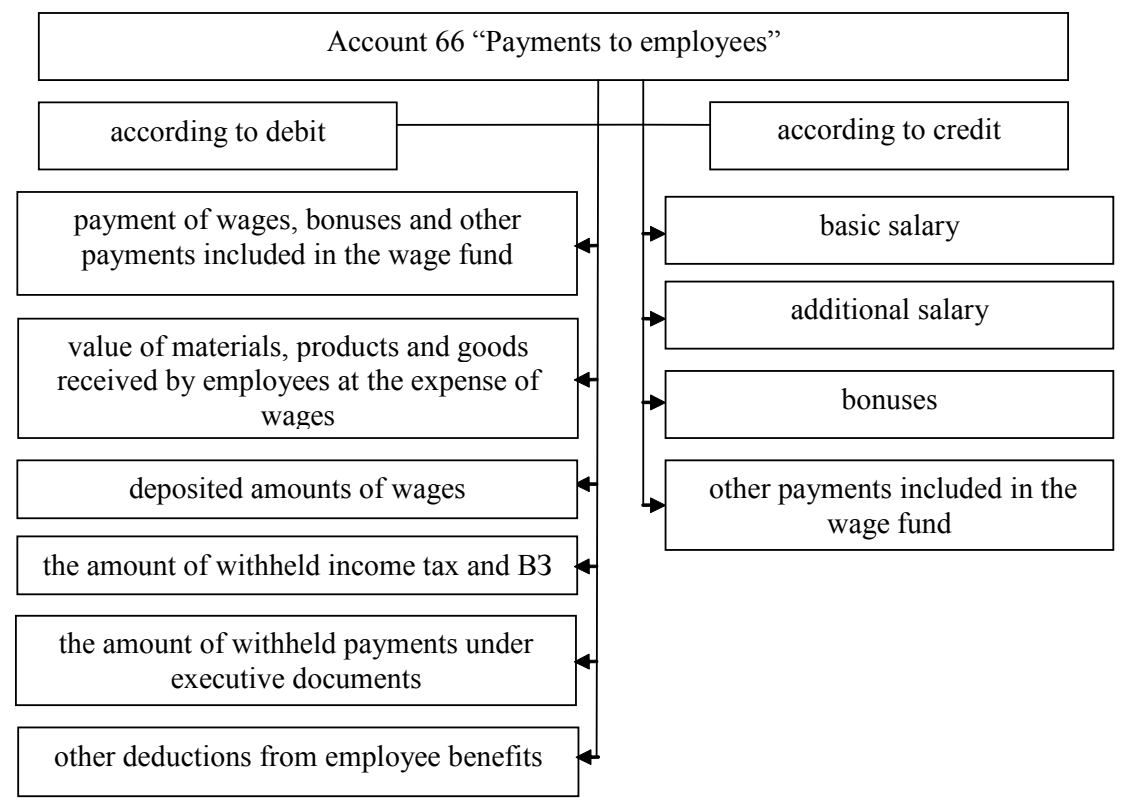

Fig. 3. Display of data on account 66 "Payments to employees" 
classification, the overall purpose of the Table 1. Offered analytical accounts to the account classification of costs is to create an orderly structure of organizational costs. Without such a structure, it is impossible to effectively keep records and link costs to facilities. Although the classification of costs is done through financial accounting, it does not always meet the information needs of management.

According to the results of the study, it is determined that payroll accounting should be a reliable source of quality information for analysis, control and management of labor costs.

Therefore, this article offers suggestions and measures for improvement to overcome the shortcomings of payroll accounting and ensure the convenience of enterprises. One of the important areas that have been identified to improve corporate accounting for a more accurate calculation of wages is the introduction of additional sub-accounts in existing analytical accounts and the provision of additional payments to employees.

Implementation of the established directions of improvement of calculation of payments to employees will allow to eliminate legislative differences, to increase efficiency of the account, to reduce expenses of time for the account of payments to employees.

\section{$\Lambda$ ітература:}

1. Про бухгалтерський облік та фінансову звітність в Україні: Закон України від 16 липня 1999 р. № 996-XIV Верховна Рада України. URL: https://zakon.rada.gov.ua/laws/show/99614 (дата звернення: 12.11.2021).

2. Maksymenko I., Melikhova T. Accounting and analytical procurement of state financial control and directions of its implementation in Ukraine. Baltic Journal of Economic Studies, Volume 3 Number 5. Riga: Publishing House "Baltija Publishing. 2017. P. 268-275.

3. Максименко I.Я., Питиляк Г.П. Особливості організації роботи 3 готівкою на підприємстві. Zbior artykulow naukowych recenzowanych. 2019. № 21. C. 33-36. URL: http://конференция.com.ua/pages/view/1289 (дата звернення: 22.11.2019).

4. Максименко I.Я. Внутрішний аудит: підвищення ефективності роботи та забезпечення прибутковості підприємства. Сталий розвиток економіки. 2013. № 1. С. 294-296.

5. Максименко I.Я., Філатова О.І. Особливості оподаткування та структура соціального пакету як інструмента матеріальної мотивації виплат працівникам. Молодий вчений. 2018. № 10 (62). C. 350-353. URL: http://molodyvche-

66 "Payments to employees"

\begin{tabular}{|l|l|l|}
\hline \multicolumn{1}{|c|}{ Account } & $\begin{array}{c}\text { Sub-account } \\
\text { and analytical } \\
\text { account code }\end{array}$ & \multicolumn{1}{|c|}{ Name of the analytical account } \\
\hline $\begin{array}{l}66 \text { "Payments to } \\
\text { employees" }\end{array}$ & 661.1 & Calculations for salaries and tariffs \\
\cline { 2 - 3 } & 661.2 & Bonuses \\
\cline { 2 - 3 } & 661.3 & Surcharges and allowances \\
\cline { 2 - 3 } & 661.4 & Other incentive payments to employees \\
\hline 661.5 & Payments for overtime \\
\hline 661.6 & Payment for vacations \\
\hline 661.7 & Temporary disability benefits \\
\cline { 2 - 3 } & 661.8 & Payment upon dismissal \\
\cline { 2 - 3 } & 661.9 & Social payments \\
\cline { 2 - 3 } & 661.10 & Payments related to downtime \\
\cline { 2 - 3 } & 661.11 & Other charges \\
\hline
\end{tabular}

ny.in.ua/files/journal/2018/10/83.pdf (дата звернення: 12.11.2021).

6. Максименко І.Я. Особливості організації обліку розрахунків за заробітною платою в процесі управління підприємством. Ефективна економіка. 2017. № 10. URL: http://www.economy.nayka.com.ua/?op=1\&z=5806 (дата звернення: 12.11.2021).

\section{References:}

1. Verkhovna Rada of Ukraine (1999), The Law of Ukraine "On accounting and financial reporting in Ukraine", available at: https://zakon.rada.gov.ua/ laws/show/996-14 (accessed: 12.11.2021).

2. Maksymenko, I. and Melikhova, T. (2017), "Accounting and analytical procurement of state financial control and directions of its implementation in Ukraine", Baltic Journal of Economic Studies, vol. 3, no. 5, pp. 268-275.

3. Maksy`menko, I.Ya. and Pytyliak, H.P. (2019), "Features of the organization of work with cash at the enterprise", Zbior artykulow naukowych recenzowanych, vol. 21, pp. 33-36, available at: URL: http://конференция.com.ua/ pages/view/1289 (accessed: 12.11.2021).

4. Maksy`menko, I. Ya. (2013), "Internal audit: improving the efficiency and profitability of the enterprise", Staly j rozvy` tok ekonomiky, vol. 1, pp. 294-296.

5. Maksy`menko, I.Ya. and Fisun, Y. O. (2018), "Features of taxation and structure of the social package how to instrument material motivation payments to workers", Molodyi Vchenyi, vol. 10 (62), pp. 350-353, available at: http://molodyvcheny.in.ua/files/journal/2018/10/83.pdf (accessed: 12.11.2021).

6. Maksy`menko, I.Ya. (2017), "Features of the organization of accounting of payments in the process of management of the enterprise", Efektyvna ekonomika, vol. 10, available at:http://www.economy.nayka.com.ua/?op=1\&z=5806 (accessed: 12.11.2021). Стаття надійшла до редакиії 13.11.2021 p. 